\title{
The continental source of glyoxal estimated by the synergistic use of spaceborne measurements and inverse modelling
}

\author{
T. Stavrakou ${ }^{1}$, J.-F. Müller ${ }^{1}$, I. De Smedt ${ }^{1}$, M. Van Roozendael ${ }^{1}$, M. Kanakidou ${ }^{2}$, M. Vrekoussis ${ }^{3}$, F. Wittrock ${ }^{3}$, \\ A. Richter ${ }^{3}$, and J. P. Burrows ${ }^{3,4}$ \\ ${ }^{1}$ Belgian Institute for Space Aeronomy, Avenue Circulaire 3, 1180, Brussels, Belgium \\ ${ }^{2}$ ECPL, Department of Chemistry, University of Crete, Heraklion, Greece \\ ${ }^{3}$ Institute of Environmental Physics, University of Bremen, Bremen, Germany \\ ${ }^{4}$ Centre for Ecology and Hydrology, Maclean Building, Benson Lane, Crowmarsh Gifford, Wallingford, \\ Oxfordshire, OX10 8BB, UK
}

Received: 15 April 2009 - Published in Atmos. Chem. Phys. Discuss.: 19 June 2009

Revised: 21 September 2009 - Accepted: 11 October 2009 - Published: 5 November 2009

\begin{abstract}
Tropospheric glyoxal and formaldehyde columns retrieved from the SCIAMACHY satellite instrument in 2005 are used with the IMAGESv2 global chemistry-transport model and its adjoint in a two-compound inversion scheme designed to estimate the continental source of glyoxal. The formaldehyde observations provide an important constraint on the production of glyoxal from isoprene in the model, since the degradation of isoprene constitutes an important source of both glyoxal and formaldehyde. Current modelling studies underestimate largely the observed glyoxal satellite columns, pointing to the existence of an additional land glyoxal source of biogenic origin. We include an extra glyoxal source in the model and we explore its possible distribution and magnitude through two inversion experiments. In the first case, the additional source is represented as a direct glyoxal emission, and in the second, as a secondary formation through the oxidation of an unspecified glyoxal precursor. Besides this extra source, the inversion scheme optimizes the primary glyoxal and formaldehyde emissions, as well as their secondary production from other identified nonmethane volatile organic precursors of anthropogenic, pyrogenic and biogenic origin.

In the first inversion experiment, the additional direct source, estimated at $36 \mathrm{Tg} / \mathrm{yr}$, represents $38 \%$ of the global continental source, whereas the contribution of isoprene is equally important (30\%), the remainder being accounted for by anthropogenic (20\%) and pyrogenic fluxes. The inversion
\end{abstract}

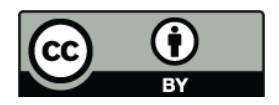

Correspondence to: T. Stavrakou (jenny@aeronomie.be) succeeds in reducing the underestimation of the glyoxal columns by the model, but it leads to a severe overestimation of glyoxal surface concentrations in comparison with in situ measurements. In the second scenario, the inferred total global continental glyoxal source is estimated at $108 \mathrm{Tg} / \mathrm{yr}$, almost two times higher than the global a priori source. The extra secondary source is the largest contribution to the global glyoxal budget (50\%), followed by the production from isoprene (26\%) and from anthropogenic NMVOC precursors (14\%). A better performance is achieved in this case, as the updated emissions allow for a satisfactory agreement of the model with both satellite and in situ glyoxal observations.

\section{Introduction}

Glyoxal (CHOCHO) and formaldehyde (HCHO) are shortlived intermediate products in the oxidation of non-methane volatile organic compounds (NMVOCs) emitted by vegetation, fires and anthropogenic activities. They are also directly emitted during fossil fuel and biofuel combustion and biomass burning. Both compounds absorb in the UVvisible spectral region and have been measured by the SCIAMACHY satellite sensor since 2003, and more recently, by the OMI and GOME-2 instruments.

Although current modelling studies succeed in reproducing reasonably well the variability and the magnitude of the observed HCHO columns (Fu et al., 2007; Barkley et al., 2008; Stavrakou et al., 2009a), a large underestimation of the glyoxal columns has been reported (Myriokefalitakis et al.,

Published by Copernicus Publications on behalf of the European Geosciences Union. 
2008; Fu et al., 2008). These discrepancies point to the existence of additional land and marine sources, and/or to an underestimation of the known sources. This study aims at determining the global distribution and strength of the glyoxal continental sources. To this purpose, we utilize synergistically $\mathrm{HCHO}$ and $\mathrm{CHOCHO}$ satellite columns in a twocompound inverse modelling framework based on the adjoint of the IMAGES model (Müller and Stavrakou, 2005). In this approach, information gained from $\mathrm{HCHO}$ can help to constrain the sources of $\mathrm{CHOCHO}$, since both gases have common precursors and are interrelated through chemistry (e.g. through the $\mathrm{OH}$ fields). Note that the focus of this study is limited to continental regions due to an inherent difficulty to retrieve $\mathrm{CHOCHO}$ columns over the oceans (interference with liquid water absorption (Wittrock et al., 2006)), and to the fact that the HCHO columns over oceanic regions lie close to the detection limit of the instrument.

The adjoint inversion model technique is used to calculate the sensitivities of the discrepancy between the model and the observations with respect to a number of emission parameters. This calculation is performed simultaneously for all the control variables, and thus, inversions at the horizontal resolution of the model can be afforded. This approach, also termed as grid-based inversion, is considered as the most efficient tool available in order to exploit the wealth of satellite measurements of reactive gases and aerosols. In particular, this method allows for addressing non-linearities and chemical interdependencies between trace gases, for refining the spatiotemporal flux distributions, while distinguishing between emission types. It has been successfully applied in the inversion of $\mathrm{CO}$ emissions (Stavrakou and Müller, 2006; Kopacz et a., 2009), $\mathrm{NO}_{\mathrm{x}}$ emissions (Stavrakou et al., 2008), secondary inorganic aerosols (Henze et al., 2009), and has been used to constrain the pyrogenic and biogenic NMVOC sources of HCHO based on a 4-year satellite dataset (Stavrakou et al., 2009b). A similar setup will be used in this study in order to derive a "topdown" inventory of the glyoxal land fluxes.

In the current inversion framework, primary formaldehyde and glyoxal emission and secondary production from NMVOC precursors (anthropogenic, biogenic and pyrogenic) are optimized for the year 2005, as well as an additional missing source of glyoxal of biogenic origin. Two inversion experiments are investigated. In the first, the extra source is assumed to be directly emitted glyoxal, and in the second, glyoxal is formed through oxidation of an unknown glyoxal precursor (UVOC) with a lifetime of five days. The impact of the choice for the UVOC lifetime is assessed through sensitivity simulations. The magnitudes and distributions of the glyoxal sources inferred by the inversion case studies are discussed, and the optimized glyoxal concentrations are evaluated against in situ measurements.

The UVOC precursor of the second inversion should not be considered as a single molecular species, but as a generic species possibly representing a collection of compounds leading to glyoxal formation after a number of non-specified intermediate steps. These compounds could be directly emitted or produced in the oxidation of short-lived biogenic precursors like terpenoids. Detailed knowledge on the oxidation mechanisms and glyoxal yield of such compounds is still lacking. Moreover, the release of glyoxal from organic aerosols is another potentially significant source of glyoxal.

The next section provides a description of the IMAGESv2 model. Particular focus is given on the description of the chemistry of the glyoxal precursors (Sect. 2.3) and to the formation of secondary organic aerosols (Sect. 2.4) due to its importance as a glyoxal loss process. A short description of the glyoxal and formaldehyde observed columns is given in Sect. 2.5. The global glyoxal budget calculated with the model is discussed in Sect. 3. The setup for the inversion and the optimization results are presented in Sect. 4. Conclusions are drawn in the last section.

\section{The model and the measurements}

\subsection{The IMAGESv2 CTM}

The global IMAGESv2 chemistry-transport model (Müller and Stavrakou, 2005; Stavrakou et al., 2009a) is run at the horizontal resolution of $4^{\circ} \times 5^{\circ}$ and is vertically discretized at 40 sigma-pressure levels extending from the surface to $44 \mathrm{hPa}$. The model calculates the concentrations of 80 trace gases using a one-day time step. Advection is driven by monthly mean ECMWF reanalysed wind fields, whereas daily ECMWF fields are used for temperature, water vapor, cloud optical depths, and planetary boundary layer mixing. Dry deposition velocities for reactive gases are calculated using a resistance-in-series scheme (Wesely, 1989), whereas the wet scavenging parameterization is thoroughly described in the Supplement : http://www.atmos-chem-phys.net/9/ 8431/2009/acp-9-8431-2009-supplement.pdf. The model accounts for the impact of diurnal variations of the chemical compounds through correction factors computed via a diurnal cycle simulation with a 20 -min time step. The diurnal profiles are also used to estimate the $\mathrm{CHOCHO}$ and HCHO concentration at the satellite overpass time (10:00 LT) from the daily averaged values calculated with a time step of one day. They depend on the location and the month. The comparison with ground-based observations uses the diurnally averaged glyoxal concentrations. This is justified since for most of the campaigns the air samples are collected during $24 \mathrm{~h}$ and the given values are daily mean concentrations. The model is confronted with the data following a 4-month initialization. The calculated monthly averaged HCHO columns account for the sampling times of observations at each location. 


\subsection{NMVOC emissions}

The model comprises emissions from 20 explicit NMVOCs (ethene, acetylene, isoprene, $\alpha$-pinene, glycolaldehyde, ethane, propane, propene, formaldehyde, glyoxal, acetaldehyde, methylglyoxal, acetone, methyl vinyl ketone, biacetyl, acetic acid, methanol, benzene, toluene and xylene). All NMVOCs are formaldehyde precursors, and among them, ethene, acetylene, isoprene, $\alpha$-pinene, glycolaldehyde, benzene, toluene, and xylene are precursors of glyoxal.

Biogenic emissions of isoprene are obtained from the MEGAN-ECMWF inventory (Müller et al., 2008). Their global estimate for 2005 is equal to $449 \mathrm{Tg}$. Emissions of monoterpenes (represented by the model compound $\alpha$ pinene) are taken from Guenther et al. (1995) and amount to $144 \mathrm{Tg} / \mathrm{yr}$. The biogenic source of methanol is calculated as in Jacob et al. (2005) and is estimated at $152 \mathrm{Tg} / \mathrm{yr}$. Other biogenic sources are as in Müller and Stavrakou (2005).

The vegetation fire emissions are provided by the Global Fire Emission Database (GFEDv2) (van der Werf et al., 2006) and the speciation from Andreae (2007). Their global estimate amounts to $95 \mathrm{Tg}$ for 2005 , including $6.5 \mathrm{Tg}$ ethene, $4.7 \mathrm{Tg}$ glycolaldehyde, $5.9 \mathrm{Tg}$ glyoxal, $1.6 \mathrm{Tg}$ benzene, $0.94 \mathrm{Tg}$ toluene and $0.28 \mathrm{Tg}$ xylene.

Biofuel emissions are estimated using emission ratios to $\mathrm{CO}$ from Andreae (2007) and biofuel CO emissions from EDGARv3.3 inventory for 1997 (Olivier et al., 2001; Olivier, 2002). In addition, emissions associated with fossil fuel use and industrial activities are provided by the POET database (Olivier et al., 2003). For acetylene, biofuel emission $(3.3 \mathrm{Tg} / \mathrm{yr})$ and technological emissions $(3 \mathrm{Tg} / \mathrm{yr})$ have been adjusted so as to reproduce aircraft campaign measurements (Xiao et al., 2007). The global anthropogenic emissions of ethene, glycolaldehyde and glyoxal are 5.4, 1.9, and $3.2 \mathrm{Tg}$, respectively. Aromatics emissions are obtained from the REanalysis of the TROpospheric chemical composition over the past 40 years (RETRO) database (Schultz et al., 2007). Their annual estimates are 3.5, 6.1 and 5.2 Tg for benzene, toluene and xylene, respectively.

\subsection{NMVOC chemistry}

The NMVOC degradation mechanism has been thoroughly presented in Stavrakou et al. (2009a). It has been designed so as to reproduce the $\mathrm{HCHO}$ yields of the quasi-explicit Master Chemical Mechanism (MCM) (Saunders et al., 2003) for pyrogenic and biogenic NMVOCs, and it has been further adjusted to account for the glyoxal production from the NMVOCs. Hereafter, updates of that mechanism regarding the glyoxal chemistry are briefly presented.

The degradation of isoprene is adapted from the Mainz Isoprene Mechanism (Pöschl et al., 2000) and has been further modified to include a production of two $\mathrm{OH}$ radicals in the reaction of first generation peroxy radicals from isoprene with $\mathrm{HO}_{2}$ (Lelieveld et al., 2008). Further, the rate of the reaction of isoprene with $\mathrm{OH}$ is reduced by $30 \%$ in order to account for the isoprene/OH segregation effect, as recommended by Butler et al. (2008). Finally, the isoprene nighttime oxidation by $\mathrm{NO}_{3}$ has been aligned with the MCM scheme. One-day box model simulations starting at 06:00 $\mathrm{h}$ under high (low) $\mathrm{NO}_{\mathrm{x}}$ levels yield a molar yield of glyoxal of $9.9 \%(8.4 \%)$, in excellent agreement with the corresponding MCM yield of $10.1 \%$ (8.8\%). For a simulation starting at $19: 30 \mathrm{~h}$, the molar glyoxal yield is estimated at $35 \%$, very close to the MCM yield of $34 \%$, under high or low $\mathrm{NO}_{\mathrm{x}}$ conditions. According to our chemical mechanism, reaction with $\mathrm{OH}$ represents $85 \%$ of the global isoprene sink, followed by ozonolysis (10\%) and oxidation by $\mathrm{NO}_{3}(5 \%)$. The calculated globally averaged molar glyoxal yield from isoprene is found to be $7.2 \%$, which is $16 \%$ higher than in Fu et al. (2008). The mean molar glyoxal yield from monoterpenes is $2.8 \%, 63.6 \%$ from acetylene, $5.7 \%$ from ethene, and $9.2 \%$ from glycolaldehyde. The formation yield of glyoxal from aromatics is taken to be the mean of the literature values reported in Arey et al. (2009): 33.3\% for benzene, 22.3\% for toluene and, taking into account for the relative contribution of o-, m-, and p-xylene in the total xylene emission (Middleton et al., 1990), the glyoxal yield from the lumped xylene compound is estimated at $17.3 \%$. Note that laboratory studies conducted under close to atmospheric conditions suggest that the glyoxal yield from toluene is higher (30.6\%; Volkamer et al. (2001)) than assumed in this study.

Other identified precursors with significant glyoxal yields, like trimethylbenzenes, ethylbenzene, ethyltoluenes, butenes, acrolein, etc. (Volkamer et al., 2005b) are not included in the model, either due to the lack of available emission data for these compounds on the global scale, or to their estimated minor contribution to the global annual glyoxal production. For instance, the global anthropogenic emission of trimethylbenzenes, estimated at $1 \mathrm{Tg} / \mathrm{yr}$ in the RETRO database (Schultz et al., 2007), would yield only about $0.04 \mathrm{Tg} / \mathrm{yr}$ of glyoxal, whereas the glyoxal produced from the degradation of methylbutenol (also not included) is estimated at $0.35 \mathrm{Tg} / \mathrm{yr}$ (Fu et al., 2008).

The glyoxal photodissociation reactions combine absorption cross sections by Volkamer et al. (2005a) with literature quantum yields from Sander et al. (2006). The OH-reaction rate is taken from Feierabend et al. (2008).

\subsection{Aerosol emissions and SOA formation}

Secondary organic aerosols (SOA) are assumed to be formed irreversibly in liquid clouds as well as on aqueous aerosols. The details of the calculation are given in the supplement: http://www.atmos-chem-phys.net/9/8431/ 2009/acp-9-8431-2009-supplement.pdf.

The irreversible uptake of glyoxal by aqueous aerosols is assumed to proceed via a uniform uptake probability, $\gamma=2.9 \times 10^{-3}$ (Liggio et al., 2005). This value has been derived from laboratory experiments conducted under 
atmospheric conditions using ammonium sulphate seed aerosols at 55\% relative humidity. Note however, that the rapidity and irreversibility of the glyoxal uptake has been questioned by Kroll et al. (2005) through experiments conducted in the absence of light and oxidants. Nevertheless, recent laboratory studies demonstrate that the uptake is greatly enhanced by the presence of oxidants and light (Volkamer et al., 2009). Another evidence for rapid glyoxal uptake is provided by direct measurements of gas-phase glyoxal (Volkamer et al., 2007), where the underestimation of the observed glyoxal concentrations can be fully accounted either through a parameterization by irreversible uptake into the aerosols with $\gamma$ equal to $3.7 \times 10^{-3}$, or through reversible partitioning to aerosol liquid water with an effective Henry's constant $K_{H}$ estimated at $4 \times 10^{9} \mathrm{M} \mathrm{atm}^{-1}$, which, although higher than the $K_{H}$ in pure water by four orders of magnitude, is found to be consistent with recent experimental values (Ip et al., 2009). Due to the high uncertainty associated to the processes leading to the SOA formation from glyoxal, two sensitivity experiments are conducted assuming either no glyoxal uptake on aerosols, or that the uptake proceeds with the coefficient $\gamma=3.7 \times 10^{-3}$ (Volkamer et al., 2007), which is by $27 \%$ higher than in Liggio et al. (2005). The results of these sensitivity studies are discussed in Sects. 3 and 4.2.

Aqueous aerosols in IMAGESv2 include liquid inorganic aerosols and hydrophilic carbonaceous aerosols. Dust and sea-salt aerosols are neglected. Inorganic aerosols (the sulfate-ammonium-nitrate-water system) are calculated using EQSAM (EQuilibrium Simplified Aerosol Model) (Metzger et al., 2002), with deliquescence relative humidities (DRH) of Nenes et al. (1998). In order to account for the hysteresis of particle phase transitions (Wang et al., 2008), inorganic aerosols are assumed to be solid only when relative humidity never exceeded the DRH in the past $24 \mathrm{~h}$. The description of sulfate formation follows Pham et al. (1995) with several improvements. Anthropogenic emissions $(72.6 \mathrm{TgS} / \mathrm{yr}$ globally) are provided by EDGAR-FT2000 (Olivier et al., 2005). Non-eruptive volcanic emissions $(7.2 \mathrm{TgS} / \mathrm{yr}$, including $2.4 \mathrm{TgS} / \mathrm{yr}$ of non- $\mathrm{SO}_{2}$ sulfur compounds emitted as $\mathrm{SO}_{2}$ in the model) are provided by Andres and Kasgnoc (1998). The GFEDv2 database and the emission ratios of Andreae (2007) result in global emissions of $1.2 \mathrm{TgS} / \mathrm{yr}$ due to vegetation fires in 2005. Natural sulfur emissions include the oceanic DMS source obtained from Dentener et al. (2006) (18.3 TgS/yr) and a small biospheric emission of $\mathrm{H}_{2} \mathrm{~S}$ (0.5 TgS/yr) (Pham et al., 1995). The model includes the gasphase oxidation of DMS and $\mathrm{H}_{2} \mathrm{~S}$ to form $\mathrm{SO}_{2}$ (and methanesulfonic acid in the case of DMS) and the $\mathrm{SO}_{2}$ oxidation by $\mathrm{OH}$ to form sulfate, with rates from Sander et al. (2006). The pH-dependent aqueous-phase oxidation of $\mathrm{SO}_{2}$ by $\mathrm{O}_{3}$ and $\mathrm{H}_{2} \mathrm{O}_{2}$ to form sulfate is included using kinetic data and Henry constants reported in Tie et al. (2001), with cloud volume fractions and liquid water content from ECMWF analyses.
Ammonia emissions due to domestic animals and synthetic fertilizers (19 TgN/yr globally) are obtained from Bouwman et al. (2002). Vegetation fires emitted 6.1 Tg NH $\mathrm{NH}_{3}$ $\mathrm{N}$ in 2005, based on GFEDv2 and emission ratios of Andreae (2007). The other $\mathrm{NH}_{3}$ emissions (totalling $19.4 \mathrm{Tg} / \mathrm{yr}$ ) are provided by the GEIA inventory (Bouwman et al., 1997). The temporal variability of emissions due to soils and manure is driven by soil temperature (Park et al., 2004), whereas the seasonal variation of emissions due to crops and fertilizers follows the number of daylight hours (Adams et al., 1999).

The emissions of organic carbon (OC) and black carbon (BC) aerosols from anthropogenic activities (Bond et al., 2004) and biomass burning (van der Werf et al., 2006) are included in the model. Both OC and BC have hydrophilic and hydrophobic components. The conversion of hydrophobic to hydrophilic $\mathrm{OC}$ and $\mathrm{BC}$ due to aging is represented by an efolding time of $6 \mathrm{~h}$ in tropical regions (Bellouin et al., 2007) and one day elsewhere (Martin et al., 2003). The mass ratio of organic matter to OC is taken to 2.1, a value valid for rural areas (Pang et al., 2006). The effective diameter of dry organic aerosols is taken to $145 \mathrm{~nm}$, based on field campaigns over Amazonia (Rissler et al., 2006) and Africa (Bellouin et al., 2007). The hygroscopic growth factor is calculated by setting the activity coefficient of water to 1.1 , a value typical for $\alpha$-pinene SOA (Compernolle et al., 2009) leading to growth factors in good agreement with field measurements over Amazonia during the dry season (Rissler et al., 2006; Mircea et al., 2006).

\subsection{Observed CHOCHO and HCHO columns}

We use glyoxal and formaldehyde column abundancies retrieved from the SCIAMACHY (Scanning imaging absorption spectrometer for atmospheric cartography) UV-visible sounder onboard ENVISAT satellite for 2005. The differential optical absorption spectroscopy (DOAS) technique (Platt et al., 1994) has been applied for both compounds. The spectral window found to be optimal for the fitting is $436-457 \mathrm{~nm}$ for CHOCHO (Wittrock et al., 2006) and 328.5-346 nm for HCHO (De Smedt et al., 2008). For CHOCHO, the Volkamer et al. (2005a) absorption cross sections are used, and for the HCHO retrieval the Cantrell et al. (1990) values shifted by $0.08 \mathrm{~mm}$ (Stavrakou et al., 2009b).

The columns are binned onto the model resolution and monthly averaged. The error on the CHOCHO columns is assumed to comprise an absolute error of $2 \times 10^{14}$ molecules $\mathrm{cm}^{-2}$ and a $30 \%$ relative error, whereas the error on the HCHO columns includes the reported retrieval error (De Smedt et al., 2008) and a model error amounting to $20 \%$ of the column, based on sensitivity calculations with the IMAGESv2 model (Stavrakou et al., 2009a). Seasonally averaged observed glyoxal and formaldehyde columns are displayed in Fig. 1. A thorough discussion on the seasonal variability of the measured columns can be found in De Smedt et al. (2008), Wittrock et al. (2006), 
and Vrekoussis et al. (2009). As this study focuses on land sources, oceanic data of both compounds are not used to constrain the inversion. Moreover, data in the vicinity of the south Atlantic anomaly $\left(26.1^{\circ} \mathrm{S}\right.$, width $=16.7^{\circ}, 47.4^{\circ} \mathrm{W}$, width $=28.4^{\circ}$, Nichitiu et al. (2004)) are also excluded.

\section{The glyoxal global budget}

The global a priori budget of glyoxal (in absence if any additional biogenic source) is summarized in Table 1. About $55 \%, 27 \%$ and $18 \%$ of the global glyoxal source are due to biogenic, anthropogenic, and pyrogenic emissions, respectively. The largest sink of glyoxal is photolysis (51\%), followed by SOA formation (22\%), OH oxidation (18\%), and dry and wet deposition (8\%). The global glyoxal source is estimated to $56 \mathrm{Tg} / \mathrm{yr}$ and the global lifetime to $2.5 \mathrm{~h}$, in good agreement with literature values $(45 \mathrm{Tg} / \mathrm{yr}, 2.9 \mathrm{~h}$ in $\mathrm{Fu}$ et al. (2008), $56 \mathrm{Tg} / \mathrm{yr}, 3 \mathrm{~h}$ in Myriokefalitakis et al. (2008)). The global annual burden, estimated at $15.8 \mathrm{Gg} / \mathrm{yr}$, is consistent with the Fu et al. (2008) estimate of $15 \mathrm{Gg} / \mathrm{yr}$, and is found to be by $20 \%$ lower than in Myriokefalitakis et al. (2008). This discrepancy is mostly due to the SOA formation sinks which are not considered in Myriokefalitakis et al. (2008).

Directly emitted glyoxal from fires constitutes the major contribution to the total pyrogenic glyoxal production $(60 \%)$, whereas the remainder is secondary production, mostly from acetylene oxidation $(24 \%)$, aromatics $(5 \%)$, glycolaldehyde $(4 \%)$, and ethylene $(7 \%)$. About $60 \%$ of the total anthropogenic glyoxal is generated through acetylene oxidation, followed by primary glyoxal (20\%), and aromatics $(15 \%)$. Biogenically emitted glyoxal is only of secondary origin, the isoprene oxidation being responsible for more than $90 \%$ of the total source, the remainder being formed from monoterpenes and ethene.

The estimated glyoxal sink associated with SOA formation in clouds $(4.7 \mathrm{Tg} / \mathrm{yr})$ is found to be in good agreement with the previous estimate of $\mathrm{Fu}$ et al. (2008), whereas the irreversible uptake on aerosols, amounting to $5.9 \mathrm{Tg} / \mathrm{yr}$ on $\mathrm{OC} / \mathrm{BC}$ and to $1.8 \mathrm{Tg} / \mathrm{yr}$ on sulfates, is significanty higher than in Fu et al. (2008). The resulting mean lifetime against SOA conversion (ca. $11 \mathrm{~h}$ ), is about two times shorter than in Fu et al. (2008). The lifetimes against photolysis and $\mathrm{OH}$ oxidation are calculated to be $4.8 \mathrm{~h}$ and $14 \mathrm{~h}$, respectively, in good agreement with the study of Myriokefalitakis et al. (2008). Note that the glyoxal aerosol sink is even higher when using the uptake coefficient taken from Volkamer et al. (2007) $\left(3.7 \times 10^{-3}\right)$ and is estimated at $9.2 \mathrm{Tg} / \mathrm{yr}$.

Annually averaged observed and simulated $\mathrm{CHOCHO}$ columns are compared in the top panels of Fig. 2. The model generally underestimates the observations over all continents. The model/data biases and spatiotemporal correlations averaged over large regions are summarized in Table 2. On the global scale, the a priori simulation underestimates the data by $57 \%$, and yields an overall correlation coefficient
Table 1. Global annual glyoxal source calculated with IMAGESv2 for 2005 in the a priori simulation and in inversions A and B. A priori and optimized flux estimates are expressed in $\mathrm{Tg} / \mathrm{yr}$.

\begin{tabular}{lccc}
\hline Sources & A priori & Inversion A & Inversion B \\
\hline Anthopogenic & & & \\
primary & 3.2 & 5 & 3.4 \\
secondary & 11.9 & 13.3 & 12.1 \\
Pyrogenic & & & \\
primary & 5.9 & 4.7 & 4.3 \\
secondary & 3.9 & 2.9 & 2.6 \\
Biogenic & 31 & 32.5 & 32 \\
UVOC & & & \\
primary & & 35.6 & \\
secondary & & & 54 \\
\hline Total & 56 & 94 & 108 \\
\hline Sinks & & & \\
Photolysis & 28.7 & 41.9 & 62.4 \\
OH oxidation & 10 & 14.1 & 18 \\
SOA in clouds & 4.7 & 9.3 & 10 \\
SOA in aerosols & 7.7 & 11.6 & 10.4 \\
Dry deposition & 2.7 & 12.1 & 3.9 \\
Wet deposition & 1.8 & 4.7 & 3.1 \\
\hline Lifetime (hr) & 2.5 & 2.4 & 2.5 \\
Burden (Gg) & 15.8 & 25 & 32.3 \\
\hline
\end{tabular}

of 0.5. The correlation is stronger over Northern America and Asia (>0.6), but falls to zero over Europe. The model/data discrepancies over the oceans are much more important (Fig. 2), but their investigation lies out of scope of this study.

The global HCHO budget is estimated at $1660 \mathrm{Tg} / \mathrm{yr}$. According to the model calculations, the global HCHO production is due to the oxidation of methane (60\%), isoprene (30\%), anthropogenic (7\%), and pyrogenic NMVOCs (3\%), whereas photolysis is the major sink (73\%), followed by the OH oxidation (23\%), and deposition (4\%) (Stavrakou et al., 2009a). Systematic comparisons between the monthly mean observed and simulated HCHO columns over a large number of regions, presented in Stavrakou et al. (2009a), show that the model captures the spatial pattern of the observed HCHO columns and succeeds quite well in reproducing the intensity of the observed maxima.

Monthly mean HCHO columns from SCIAMACHY are compared to modelled columns (Fig. 3, right) averaged over several tropical regions. The seasonality and intensity of the observed HCHO columns are well reproduced by the model, except for an overestimation over Indonesia and an underestimation over southern Africa. The comparisons for glyoxal on the same figure confirm the model underestimation noted above. Furthermore, in many cases, the seasonality of the observed columns is severely misrepresented. 

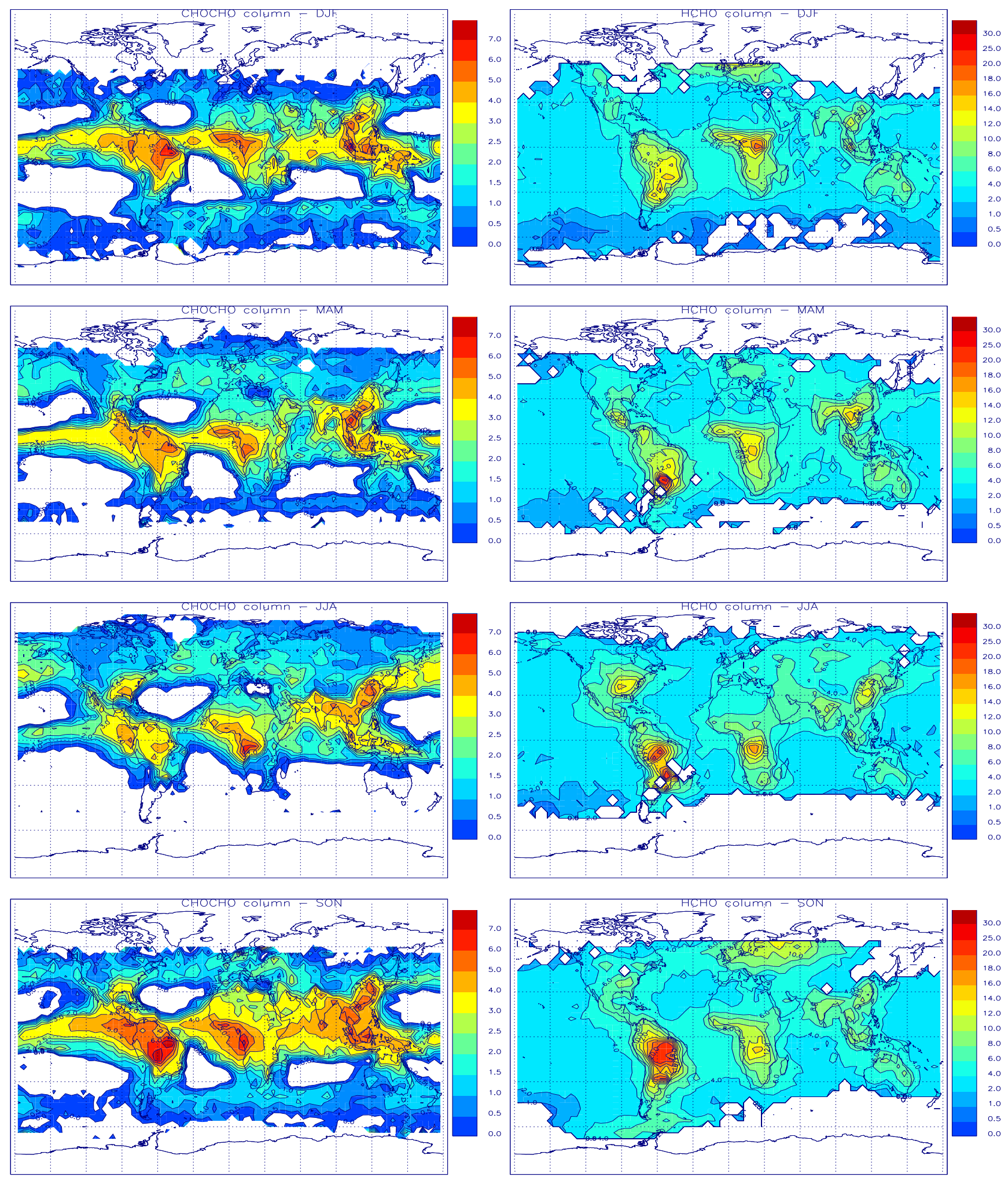

Fig. 1. Averages of the observed CHOCHO (left, in $10^{14}$ molecules $\mathrm{cm}^{-2}$ ) and $\mathrm{HCHO}$ (right, in $10^{15}$ molecules $\mathrm{cm}^{-2}$ ) vertical columns for winter (DJF), spring (MAM), summer (JJA) and autumn (SON) 2005. Blank regions correspond to an absence of valid data due to large zenith angles, south Atlantic Anomaly, or missing cloud information. 

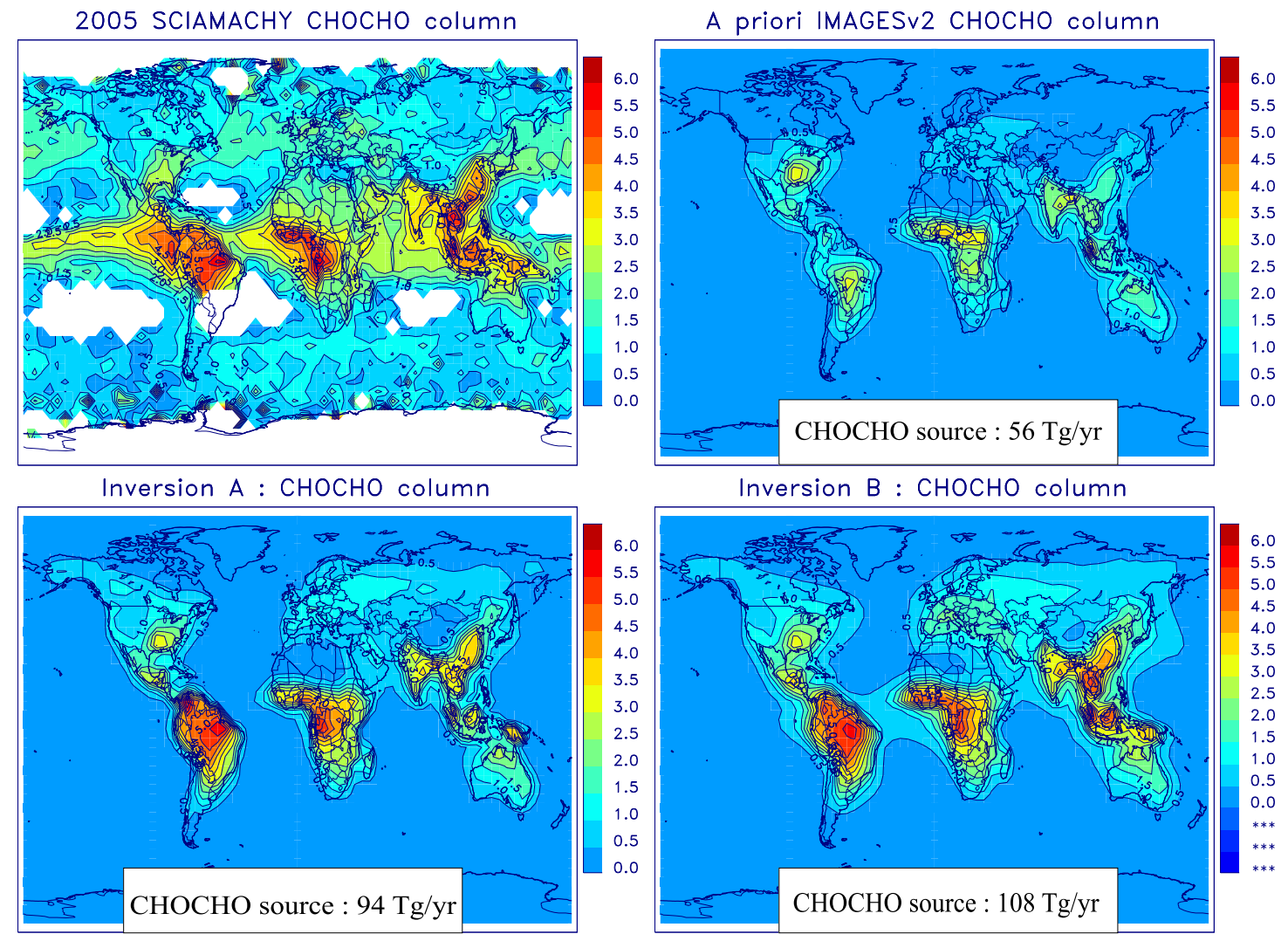

Fig. 2. Annually averaged CHOCHO vertical columns observed (top left), simulated with IMAGESv2 (top right), and deduced from inversion (bottom panels). The global annual CHOCHO source for each case is given inset. Units are $10^{14}$ molecules $\mathrm{cm}^{-2}$.

\section{Inverse modelling}

\subsection{Setup for the inversion}

The full (transport and chemistry) adjoint of the IMAGES model (Müller and Stavrakou, 2005) is used for deriving updated emission estimates. The inorganic aerosol surface densities, computed by the EQSAM module, are calculated in the forward mode and are kept constant throughout the inversion. The model does not include an adjoint for the SOA formation module, and thus, the effects of the SOA concentration changes on the glyoxal sink are not accounted for. The inversion is performed on a grid cell basis, i.e. the fluxes are updated at every grid cell and month (Stavrakou and Müller, 2006; Stavrakou et al., 2009b), except when the a priori emissions are very small (see below). Four emission categories are optimized : I) anthropogenic NMVOC emissions of glyoxal and its precursors (except for acetylene) II) all pyrogenic NMVOCs, as in Stavrakou et al. (2009b)), III) identified biogenic NMVOC precursors (BVOC) (isoprene, monoterpenes, methanol, and ethene), and IV) unidentified biogenic VOCs (UVOC). The global a priori UVOC source is distributed as the leaf area index obtained from the Moderate
Resolution Imaging Radiospectrometer (MODIS) satellite (http://modis.gsfc.nasa.gov/data/atbd/) and is scaled globally to $20 \mathrm{Tg} / \mathrm{yr}$ (Figs. 4,4.2 upper panel).

Emissions are not optimized in grid cells with very low emissions. An emission parameter is optimized in a grid cell only when the a priori maximum flux in this cell is higher than $10^{10}$ molecules $\mathrm{cm}^{-2} \mathrm{~s}^{-1}$ for the first three categories and $5 \times 10^{8}$ molecules $\mathrm{cm}^{-2} \mathrm{~s}^{-1}$ for the latter. The thresholds have been adjusted so as to ensure that there are enough control variables from each emission category to be inferred by the inversion. The total number of control parameters is equal to ca. 30000 . The errors on the emission parameters are assumed to be factor of two. Correlations between the a priori errors on the control parameters are introduced through the off-diagonal elements of the error covariance matrix, in the same way as in Stavrakou et al. (2009b) for the inversion using $\mathrm{HCHO}$ data.

Among the above-mentioned species, isoprene, monoterpenes, glycolaldehyde, and ethene are precursors of both glyoxal and formaldehyde. Although the chemical feedbacks between glyoxal and formaldehyde are weak, performing a simultaneous inversion of both species constitutes the best way to take advantage from the constraints provided from 

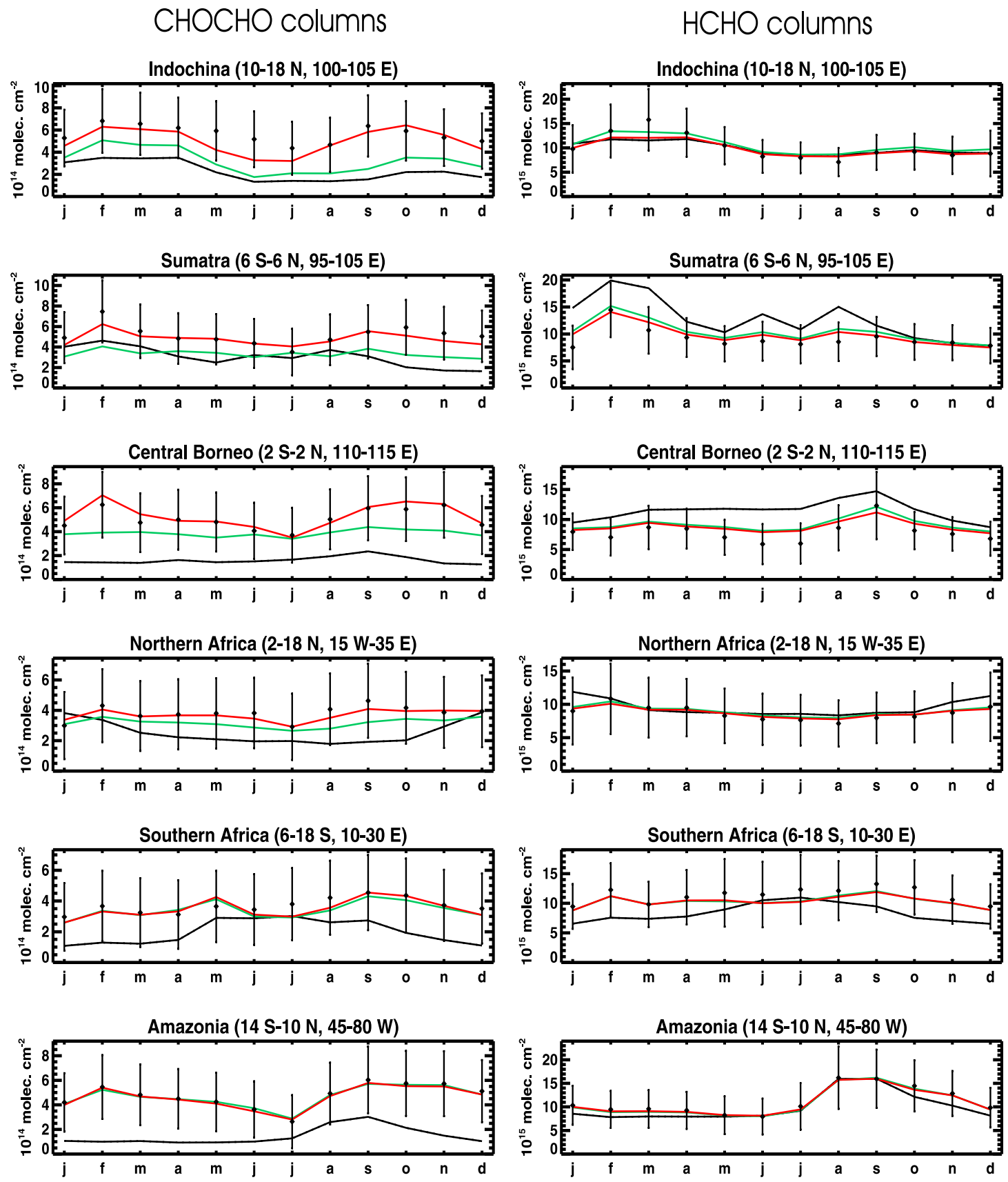

Fig. 3. Monthly mean CHOCHO (left) and HCHO (right) column abundancies simulated with IMAGESv2 and observed by SCIAMACHY (black dots) in 2005. Black solid lines correspond to the a priori simulation, green and red to inversions A and B, respectively. CHOCHO columns are expressed in $10^{14}$ molecules $\mathrm{cm}^{-2}$ and HCHO columns in $10^{15}$ molecules $\mathrm{cm}^{-2}$.

both satellite datasets, while accounting for all chemical interdependencies.

Two inversion experiments are conducted. In inversion A, UVOC is directly emitted glyoxal, whereas in inversion B, UVOC forms glyoxal upon oxidation by $\mathrm{OH}$ with a molar yield of unity and a reaction rate of $2.86 \times 10^{-12}$ molecules ${ }^{-1} \mathrm{~cm}^{3} \mathrm{~s}^{-1}$, which is adjusted so that the global lifetime of UVOC is equal to five days. Sensitivity calculations with shorter and longer lifetimes for UVOC will also be addressed. 
Table 2. Mean model/data biases and spatiotemporal correlation coefficients per region calculated for the a priori simulation, and after the inversions A and B.

\begin{tabular}{lcccccc}
\hline Regions & \multicolumn{2}{c}{ A priori } & \multicolumn{2}{c}{ Inversion A } & \multicolumn{2}{c}{ Inversion B } \\
\hline & Bias & $r$ & Bias & $r$ & Bias & $r$ \\
\hline N. America (30-70 N, 60-170 W) & -48.6 & 0.66 & -21.4 & 0.65 & -19.5 & 0.67 \\
Tropical America (30 S-20 N, 30-80 W) & -63.7 & 0.43 & -3.2 & 0.86 & -2.5 & 0.84 \\
Europe (35-65 N, 10 W-55 E) & -62.8 & 0.00 & -32.2 & 0.05 & -7.6 & 0.12 \\
Africa (40 S-30 N, 20 W-45 E) & -54.2 & 0.47 & -31.0 & 0.66 & -26.2 & 0.70 \\
Asia (10 S-55 N, 60-160 E) & -54.8 & 0.62 & -23.8 & 0.74 & -9.7 & 0.85 \\
Oceania (10-40 S, 110-170 E) & -17.3 & 0.57 & -6.3 & 0.75 & -5.6 & 0.72 \\
\hline Globe & -56.9 & 0.50 & -26.7 & 0.73 & -18.7 & 0.77 \\
\hline
\end{tabular}

Table 3. Comparison between in situ measurements of glyoxal concentrations, a priori concentrations, and concentrations inferred by the inversions. Numbers are in ppt. RMSD is the root mean square deviation. References: (1) Lee et al. (1995), (2) Lee et al. (1998), (3) Munger et al. (1995), (4) Spaulding et al. (2003), (5) Ieda et al. (2006), (6) Matsunaga et al. (2004), (7) Moortgat et al. (2002).

\begin{tabular}{llcccc}
\hline Location & Time & Observ. & A priori & A & B \\
\hline Georgia (32.5 N, 82 W) (1) & Jul-Aug 1991 & 18.0 & 65.1 & 132.6 & 55.4 \\
Georgia (32.5 N, 82W) (1) & Jun 1992 & 83.0 & 48.8 & 132.6 & 45.9 \\
Nashville (37 N, 87 W) (2) & Jul 1995 & 67.0 & 89.0 & 64.7 & 58.5 \\
Nashville (37 N, 87 W) (2) & Jul 1995 & 26.0 & 31.9 & 13.8 & 17.9 \\
Pinnacles (39 N, 78 W) (3) & Sept. 1990 & 44.0 & 48.9 & 138.1 & 51.0 \\
Blodgett Forest (39 N, 120 W) (4) & Aug-Sep 2000 & 27.0 & 25.4 & 59.4 & 31.1 \\
Tomakomai (42.7 N, 141.6 E) (5) & Sep 2003 & 26.0 & 7.4 & 45.3 & 19.3 \\
Uryu, Japan (44.3 N, 142.2 E) (6) & Aug 2002 & 18.0 & 13.2 & 70.8 & 27.2 \\
Pabsthum (52.5 N, 12.5 E) (7) & Aug 1998 & 38.0 & 18.8 & 67.6 & 26.3 \\
\hline Average bias (pptv) & & & 0.14 & 34.3 & -1.3 \\
RMSD & & & 6.2 & 15.7 & 5.2 \\
\hline
\end{tabular}

\subsection{Results}

Inferred annual mean glyoxal columns from both inversions are illustrated in Fig. 2. In both cases the inversion reproduces reasonably well the observations, although an underestimation persists due to the a priori constraints on the emissions. Inversion $\mathrm{B}$, however, provides a better match with the observed patterns and magnitudes over the continents, as well as near the coasts over the tropical oceans, due to the secondary glyoxal production from UVOC inside the transported air masses. The columns inferred from inversion A (Fig. 3, green) remain too low over southeast Asia and miss the observed seasonality, whereas the deduced columns from inversion B allow for an excellent model/data agreement over all displayed regions. Overall, the globally averaged relative bias over land is decreased from $-57 \%$ in the a priori, to $-27 \%$ and $-19 \%$ in scenarios A and B, respectively, whereas the spatiotemporal correlation coefficient increases from 0.5 in the a priori to 0.73 and 0.77 in cases A and B. The lowest biases $(<-10 \%)$ and highest correlations $(>0.8)$ are obtained over Tropical America in both inversions, and over Asia in inversion B.

The a priori and optimized annual global distribution of the UVOC source is displayed in Fig. 4. The a priori flux and the ratios of the optimized by the a priori fluxes for the different emission categories are illustrated in Figs. 5 and 6. The column enhancement of inversion A (Fig. 2) is achieved by strengthening the primary UVOC source to $36 \mathrm{Tg} / \mathrm{yr}$, and by moderately increasing anthropogenic emissions as well as biogenic fluxes (Table 1). The optimized isoprene source amounts to $476 \mathrm{Tg} / \mathrm{yr}$, and is equal to the inferred isoprene source from a previous inversion constrained by $\mathrm{HCHO}$ columns (Stavrakou et al., 2009b). A similar increase in the isoprene source is deduced from the experiment $\mathrm{B}$, whereas the secondary UVOC source is estimated at $56 \mathrm{Tg} / \mathrm{yr}$. The optimized tropical UVOC source $(40 \mathrm{Tg} / \mathrm{yr})$ represents two thirds of the total UVOC source and is strongly enhanced with respect to its a priori value. 
A priori UVOC emissions

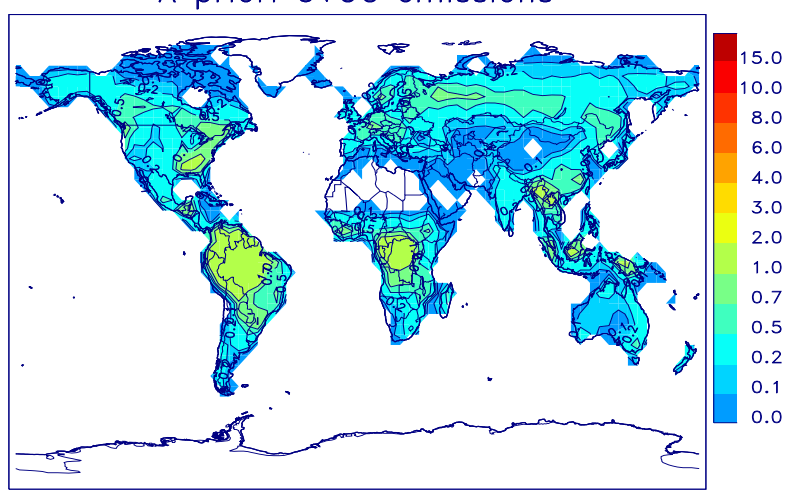

A posteriori UVOC emissions - Inv. A

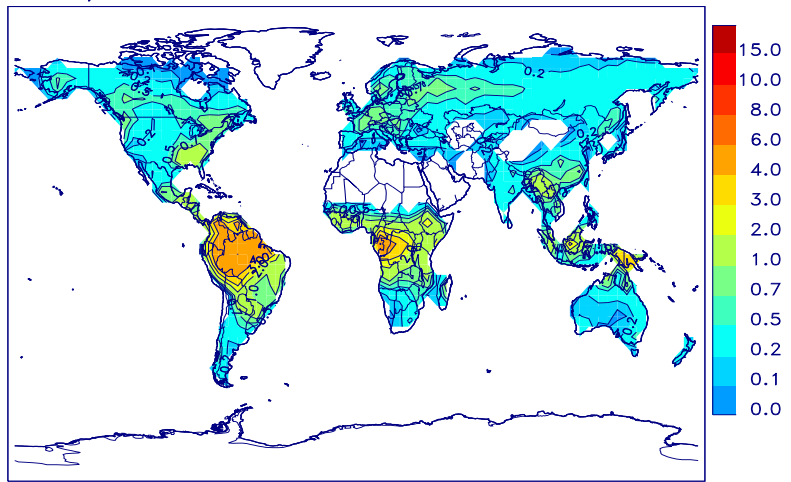

A posteriori UVOC emissions - Inv. B

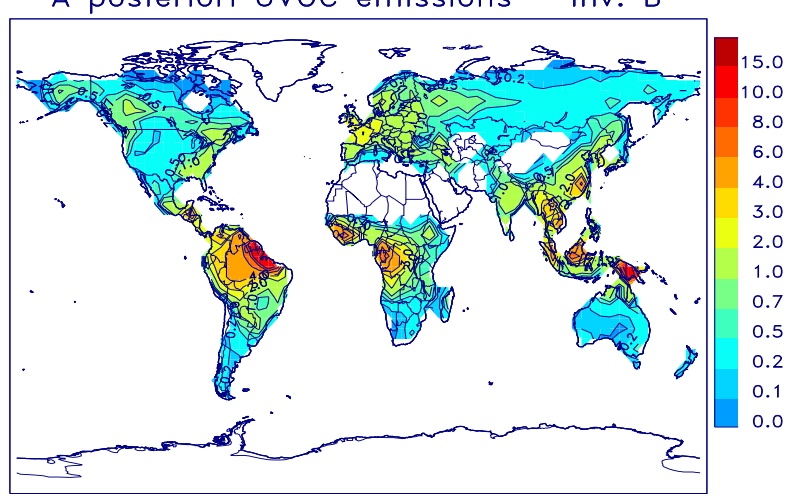

Fig. 4. Global annual distribution of the additional glyoxal precursor (UVOC) source inferred by the inversions. Units are $10^{10}$ molecules $\mathrm{cm}^{-2} \mathrm{sec}^{-1}$.

A decrease by about $20 \%$ is found for the pyrogenically emitted NMVOCs in both inversions. The inferred global terrestrial source amounts to $94 \mathrm{Tg} / \mathrm{yr}$ in inversion A and to $108 \mathrm{Tg} / \mathrm{yr}$ in inversion B. At the continental scale, the derived mean annual isoprene flux decrease by $25 \%$ over Northern America and the strong increase over southern Africa are similar to the inversion results using only HCHO columns (Stavrakou et al., 2009b). The a posteriori anthropogenic emissions are enhanced compared to the a priori, especially over the Far East, where the increase exceeds a factor of two
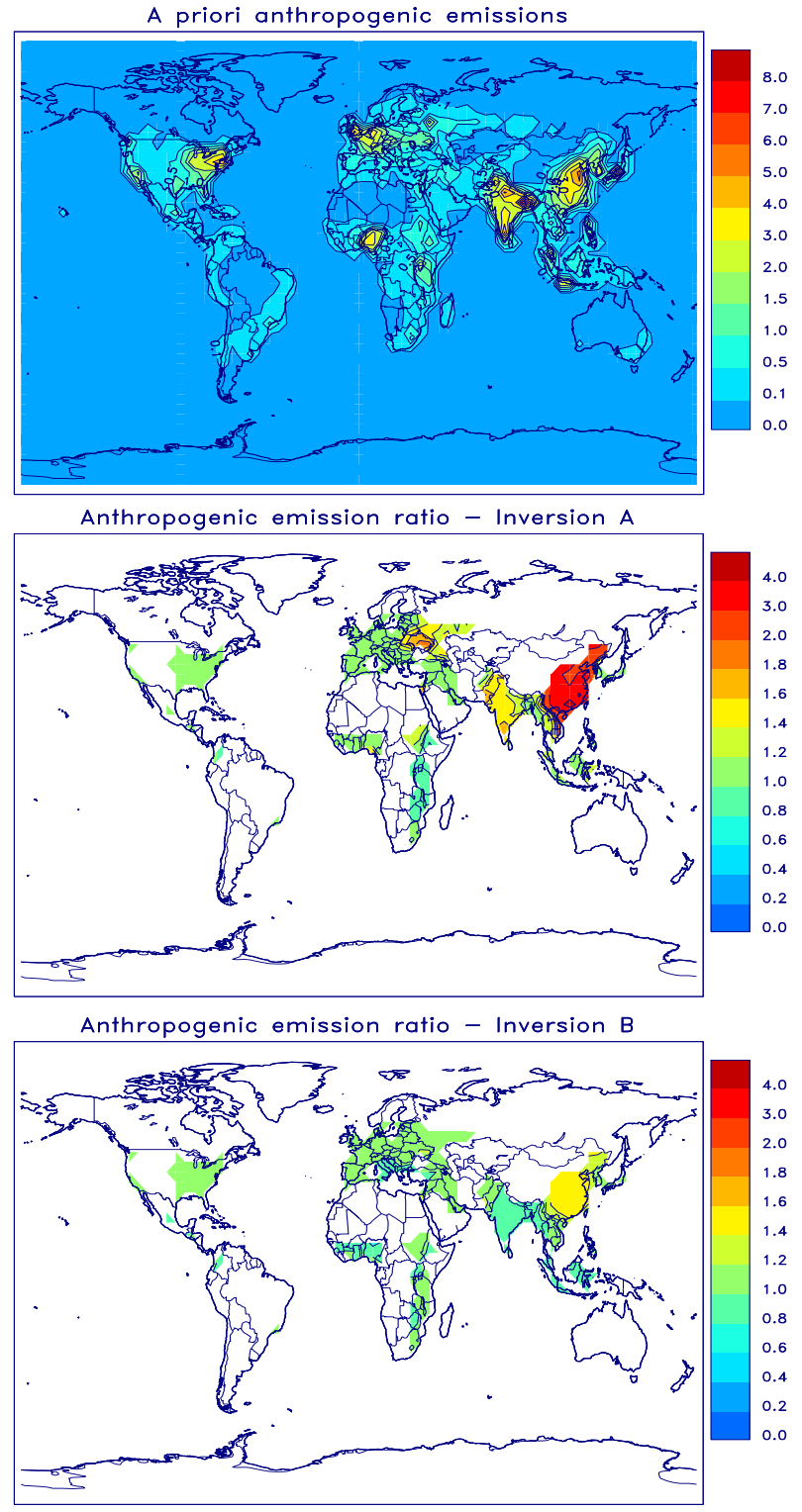

Fig. 5. Global annual a priori anthropogenic flux of glyoxal precursors, and the ratio of the optimized by the a priori estimate inferred by the inversion studies.

in inversion A. Further, the pyrogenic emissions inferred over Northern Africa are decreased by 50\%, in qualitative agreement with previous studies (Myriokefalitakis et al., 2008).

The uncertainties associated to the aforementioned glyoxal source estimates are large, but difficult to quantify. They are mostly due to possible biases in the satellite retrievals, to uncertainties in the chemical mechanisms of the NMVOCs, and to the representation of the glyoxal sinks in the model. 

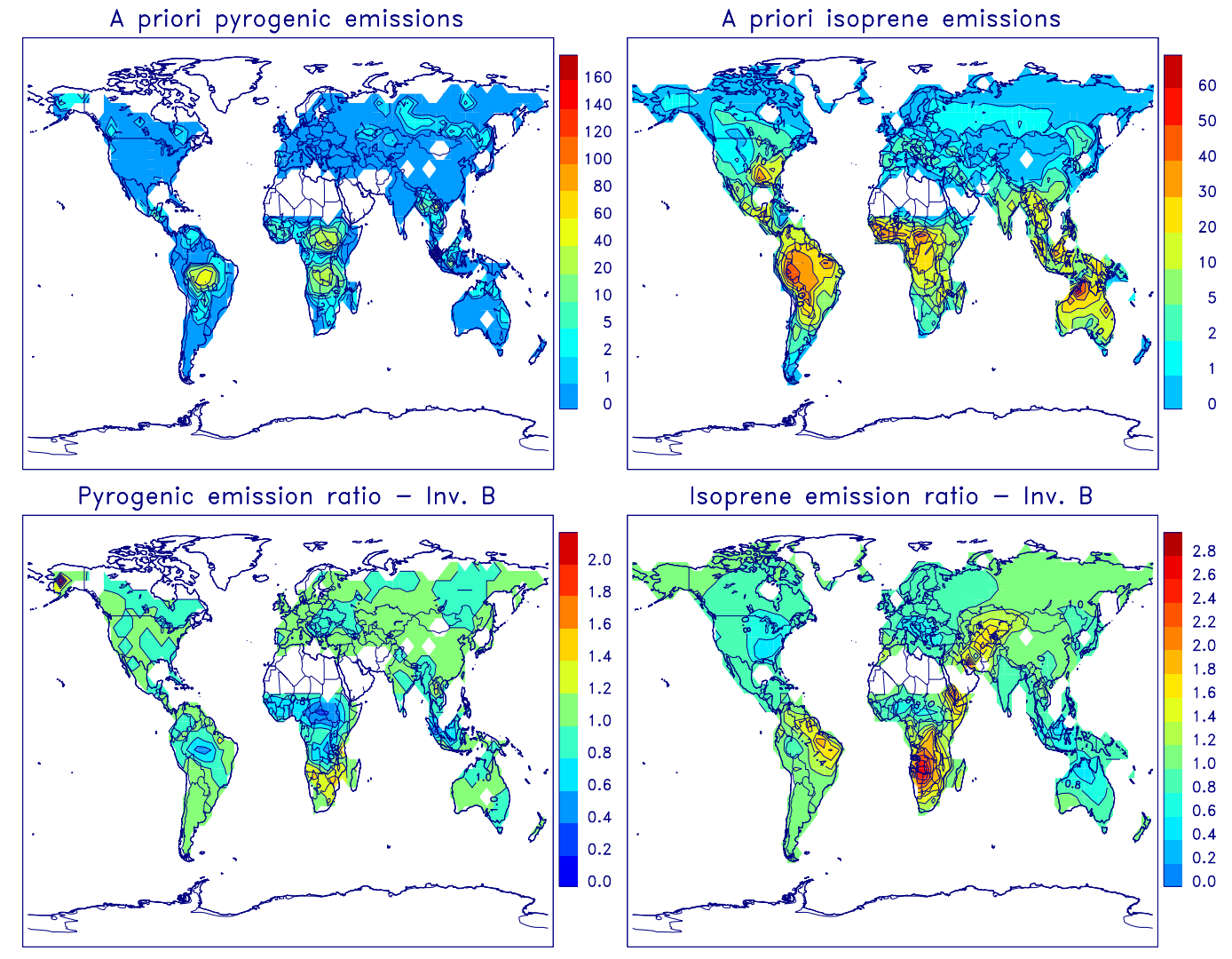

Fig. 6. Global annual a priori pyrogenic NMVOC and biogenic isoprene emissions (upper panel) and the ratios of the optimized by the a priori fluxes deduced by the inversion B (lower panel).

Table 4. Description of the performed sensitivity studies. The columns represent the global mean model/data biases $(b)$ and spatiotemporal correlation coefficients $(r)$, the average biases $b_{\text {situ }}$ in pptv and the root mean square deviations (RMSD) calculated from the comparisons between the in-situ measurements of Table 3 and the glyoxal concentrations derived by the inversions.

\begin{tabular}{clcccc}
\hline Scenario & Description & $b$ & $r$ & $\mathrm{~b}_{\text {situ }}$ & RMSD \\
\hline B & standard, a priori UVOC source $=20 \mathrm{Tg} / \mathrm{yr}$, & & & & \\
& UVOC lifetime $=5$ days, $\gamma=2.9 \times 10^{-3}$ & -18.7 & 0.77 & -1.3 & 5.2 \\
$\mathrm{C}$ & as B, without aerosol uptake of glyoxal & -18.3 & 0.76 & 1.1 & 5.4 \\
$\mathrm{D}$ & as B, but $\gamma=3.7 \times 10^{-3}$ & -18.8 & 0.77 & -2.0 & 5.1 \\
$\mathrm{E}$ & as B, UVOC lifetime $=1$ day & -20.9 & 0.77 & 3.7 & 5.6 \\
$\mathrm{~F}$ & as B, UVOC lifetime $=20$ days & -13.0 & 0.77 & -4.6 & 5.3 \\
$\mathrm{G}$ & as B, a priori UVOC source $=80 \mathrm{Tg} / \mathrm{yr}$ & -13.8 & 0.71 & 1.0 & 5.2 \\
\hline
\end{tabular}

Comparisons with surface glyoxal concentration measurements at continental mid-latitude sites of the Northern Hemisphere are provided in Table 3 and Fig. 7. Whereas a closeto-zero average bias is calculated in the a priori simulation (without UVOC source), inversion A leads to a strong overestimation (+34 ppt), which would have been even larger if the settings of the inversion (e.g. a priori errors on the emission parameters) were chosen so as to allow for a better match with the satellite data. The computed bias after optimization
B is very close to the a priori, whereas its slightly negative value is explained by the inferred decrease of the isoprene emissions over Northern America, as illustrated on Fig. 6. Further, the root mean square deviation in inversion B is by $16 \%$ lower than in the a priori. These comparisons suggest that the space-based glyoxal columns are compatible with the available in situ measurements when the extra glyoxal source is assumed to be secondary. However, in situ glyoxal measurements in tropical continental regions, certainly critical in 


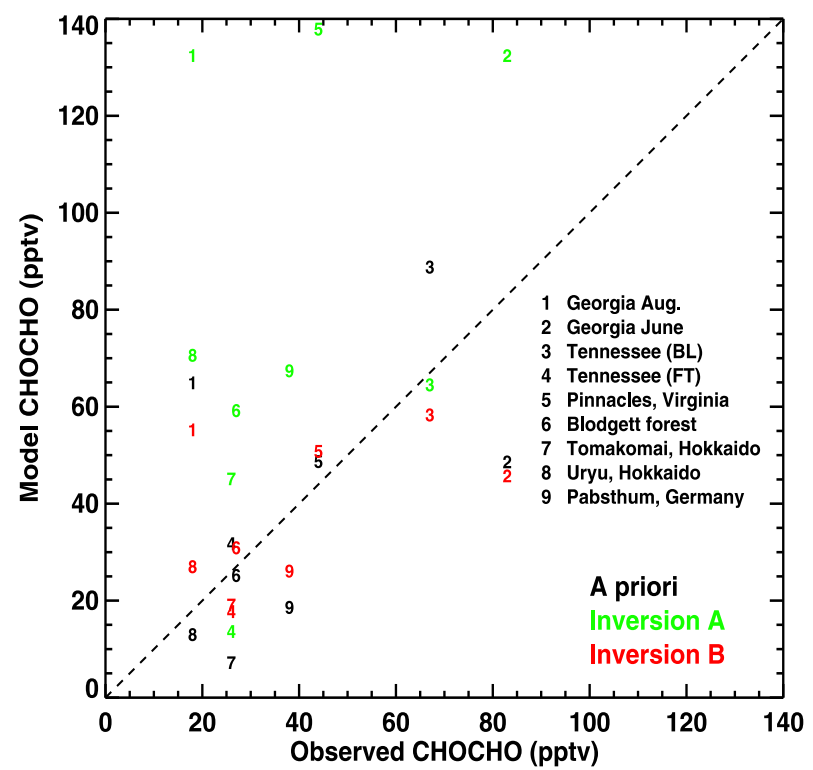

Fig. 7. In situ measurements of glyoxal vs. a priori (in black) and optimized (in green for inversion A and red for inversion B) glyoxal concentrations (see Table 3 ).

order to evaluate the model findings, are currently missing from the literature.

The sensitivity tests C and D use the setup of inversion B (Table 4). Aerosol uptake of glyoxal is ignored in inversion C and a higher uptake probability is assumed in inversion D (see Sect. 2.4). The results show that our conclusions regarding the magnitude of the UVOC source and the agreement with the independent measurements of Table 3 do not depend significantly on the assumptions made for the uptake of glyoxal by aerosols. More precisely, when ignoring the SOA formation sink on aerosols, the inferred global glyoxal and UVOC flux amount to $95 \mathrm{Tg} / \mathrm{yr}$ and $45 \mathrm{Tg} / \mathrm{yr}$, respectively, and the global glyoxal lifetime is by $16 \%$ longer $(2.9 \mathrm{~h}) \mathrm{com}$ pared to the lifetime of inversion $\mathrm{B}$. The agreement with the ground-based measurements is similar to that of inversion B, except for the mean average bias (Tables 3 and 4 ) which becomes positive in this inversion (1.1 pptv) due to the longer residence time of glyoxal near the surface. When the higher value $\gamma=3.7 \times 10^{-3}$ for the uptake coefficient is used, the estimated global annual UVOC and glyoxal source, and the glyoxal lifetime are quite similar to those of inversion B, namely, $57 \mathrm{Tg}, 110 \mathrm{Tg}$ and $2.6 \mathrm{~h}$, respectively, whereas the predicted SOA sink on aerosols amounts to $13.2 \mathrm{Tg} / \mathrm{yr}$. In this case, the average bias with the observations of Table 3 is calculated to be -2 pptv (Table 4 ).

However, the results show a stronger sensitivity to the choice of the UVOC lifetime. Sensitivity tests where the UVOC lifetime ranges between one (inversion E) and 20 days (inversion $\mathrm{F}$ ) give results qualitatively similar to inversion $\mathrm{B}$, with inferred global terrestrial glyoxal source

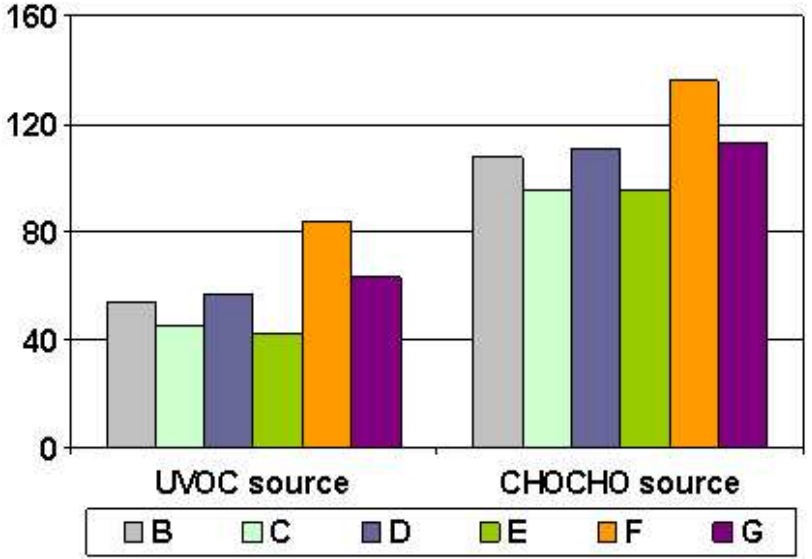

Fig. 8. Global UVOC and glyoxal source inferred from the performed sensitivity inversions of Table 4 . Units are $\mathrm{Tg} / \mathrm{yr}$.

estimated between $96-138 \mathrm{Tg} / \mathrm{yr}$, and UVOC flux between 42 and $84 \mathrm{Tg} / \mathrm{yr}$. These inversions underestimate the satellite data by $13-21 \%$, whereas the agreement with in situ measurements worsens compared to the case B results. Inversions with UVOC lifetimes shorter than one day give results more similar to the inversion A, and lead to a significant overestimation of the surface glyoxal mixing ratio. Furthermore, in order to provide a possible upper bound for the missing source, we have performed an inversion exercise $(G)$ where the a priori global UVOC source strength is assumed to be four times higher than in the standard setup, i.e. $80 \mathrm{Tg} / \mathrm{yr}$. The a priori global $\mathrm{CHOCHO}$ source is then estimated at $134 \mathrm{Tg} / \mathrm{yr}$. The inversion decreases the UVOC source to $63 \mathrm{Tg} / \mathrm{yr}$, which is $17 \%$ higher than in inversion $\mathrm{B}$, and lies within the derived UVOC source range from the inversions $\mathrm{E}$ and $\mathrm{F}$, whereas the estimated global $\mathrm{CHOCHO}$ source is only slightly higher compared to inversion B (113 Tg/yr). A comparison between the global UVOC and CHOCHO source derived by the different inversion experiments is given in Fig. 8 .

Both optimizations A and B improve significantly the modelled HCHO column, bringing it much closer to the observations (Fig. 3). This is achieved mostly by decreasing the Indonesian biogenic fluxes by up to $40 \%$, by strongly increasing the isoprene emissions over southern Africa, and by a significant reduction of the North American isoprene emissions, in line with previous inversion results using only HCHO columns (Stavrakou et al., 2009b). The interested reader is referred to the aforementioned publication for a thorough discussion on the derived isoprene flux estimates by region and a comparison with previously reported literature estimates.

Overall, the globally inferred changes in the $\mathrm{NO}_{\mathrm{x}}$ and ozone concentrations are small. The largest changes occur near the surface over tropical regions, and are mostly driven by the isoprene updates. In particular, the strong increase of the isoprene source over Southern Africa and the Amazon 
basin (Fig. 6) leads to a decrease of the annually averaged $\mathrm{OH}$ concentrations by $10-40 \%$, and to lower $\mathrm{NO}_{2}$ and ozone mixing ratios by $4-6 \%$ over these regions, whereas over the tropical Atlantic and the southern Indian Ocean the $\mathrm{NO}_{2}$ concentrations increase by $5-20 \%$, due to the transport of nitrates generated from the oxidation of isoprene over the continental regions. In constrast, the $\mathrm{OH}$ concentrations are found to be decreased by $40 \%$ near the surface over the eastern US and by $70 \%$ over Indonesia, in response to the reduced isoprene source over these regions. A decrease of 5$20 \%$ of the $\mathrm{NO}_{2}$ mixing ratio and a slight decrease (up to $4 \%$ ) of the ozone concentrations is foundd over the eastern Indian Ocean and the tropical Pacific. Over China, the $\mathrm{OH}$ mixing ratio decrease associated to the strong increase of the UVOC and glyoxal source is compensated by an enhanced $\mathrm{HO}_{2}$ production through glyoxal photolysis, which under the high $\mathrm{NO}_{\mathrm{x}}$ regime of this region, leads to an increase of ozone concentration by $2.5 \%$.

It is worth mentioning, however, that in the light of the recent work by Lelieveld et al. (2008) and Peeters et al. (2009), the currently used degradation mechanism of isoprene, which is based on the Master Chemical Mechanism, should go through a substantial revision, and therefore, the formaldehyde and glyoxal yields from isoprene might be quite different from those assumed by the MCM and used in this study. This introduces an important uncertainty in our results that is difficult to estimate.

\section{Conclusions}

The continental source of glyoxal has been constrained by glyoxal and formaldehyde columns retrieved from the SCIAMACHY sensor for 2005, based on a two-compound gridbased inversion scheme using the IMAGESv2 CTM and its adjoint. Formaldehyde provides a useful constraint on the emissions of isoprene, an important precursor of both glyoxal and formaldehyde. Fluxes of anthropogenic, pyrogenic, identified biogenic NMVOCs, and uncharacterized organic compounds (UVOC), initially distributed as the MODIS leaf area index, are determined by the inversion. Two possibilities have been explored. The UVOC is either direct glyoxal flux (case A) or an unknown glyoxal precursor with a lifetime of five days (case B).

The continental glyoxal source $(56 \mathrm{Tg} / \mathrm{yr}$ in the a priori), is estimated at $94 \mathrm{Tg} / \mathrm{yr}$ in inversion A, including a primary UVOC source of $36 \mathrm{Tg} / \mathrm{yr}$, and at $108 \mathrm{Tg} / \mathrm{yr}$ in inversion $\mathrm{B}$, including a secondary UVOC source of $54 \mathrm{Tg} / \mathrm{yr}$. The isoprene source, a major contributor to the global glyoxal source, exhibits only a slight increase with respect to its priori value on the global scale, but large deviations at the continental scale, in agreement with an inversion study constrained by formaldehyde columns only (Stavrakou et al., 2009b). Global anthropogenic fluxes are enhanced over the Far East, especially in inversion A, but stay close to their a priori values over other regions. Pyrogenic emissions are reduced by $25 \%$ on the global scale, the decrease being more important over the African continent. The emission updates enable significant reduction of the model/data discrepancies for the glyoxal and formaldehyde, demonstrating the capability to reconcile the two datasets in a single scheme. The global mean model/data bias, $-57 \%$ in the a priori simulation, is reduced to $-27 \%$ and to $-19 \%$ in inversions $\mathrm{A}$ and $\mathrm{B}$, respectively, whereas the globally calculated spatiotemporal correlation coeficient increases from 0.5 to 0.77 in inversion $\mathrm{B}$.

Validation using in situ glyoxal measurements in rural settings suggests that the missing glyoxal source is secondary (inversion B), since a large additional direct emission of glyoxal (inversion A) leads to a large overestimation of surface glyoxal concentrations. However, the lack of in situ measurements in the continental tropics makes difficult to evaluate the model results over these strongly emitting regions. Note also that errors in the satellite retrievals, the chemical degradation mechanisms, and the a priori spatiotemporal flux distribution may introduce significant uncertainties in the estimated sources. Further, the inferred glyoxal source depends on the choice of the UVOC lifetime and could range between 96 and $138 \mathrm{Tg} / \mathrm{yr}$, according to sensitivity calculations, whereas it is found to be weakly sensitive to the choice of the uptake coefficient in the parameterization of SOA formation sink from aerosols. This sink, estimated between $10 \mathrm{Tg} / \mathrm{yr}$ and $13 \mathrm{Tg} / \mathrm{yr}$, is found to be much higher than in a previous model study (Fu et al., 2008). The large relevance of SOA formed from aqueous aerosols has been also pointed out in Volkamer et al. (2009). More work is definitely needed in order to improve the representation of these processes in large scale models.

More glyoxal measurements, both space-based and in situ, would be a valuable contribution to our understanding of the emission mechanisms, the precursors of this compound, as well as the chemical mechanism controlling the local glyoxal concentrations.

Acknowledgements. This work has been supported by the PRODEX programme of the ESA funded by the Belgian Science Policy, and has been in part facilitated by funding by the University of Bremen, the State of Bremen, the German Aerospace, DLR, and EU through the ACCENT Network. We thank the DLR and ESA for the provision of the level 0 data from SCIAMACHY, used in this study. M. Vrekoussis acknowledges the A. v. Humboldt foundation and the European Union (Marie Curie) for consecutive research fellowships. The authors would like to thank the Editor for his comments which helped to substantially improve the manuscript.

Edited by: R. Volkamer 


\section{References}

Adams, P. J., Seinfeld, J. H., and Koch, D. M.: Global concentrations of tropospheric sulfate, nitrate, and ammonium aerosol simulated in a general circulation model, J. Geophys. Res., 104(D11), 13791-13823, 1999.

Andreae, M. O. and Merlet, P.: Emission of trace gases and aerosols from biomass burning, Global Biogeochem. Cy., 15, 955-966, 2001, and updates from Andreae, M. O., personal communication, 2007 .

Andres, R. J. and Kasgnoc, A. D.: A time-averaged inventory of subaerial volcanic sulfur emissions, J. Geophys. Res., 103, 25251-25261, 1998.

Arey, J., Obermeyer, G., Aschmann, S. M., Chattopadhyay, S., Cusick, R. D., and Atkinson, R.: Dicarbonyl Products of the $\mathrm{OH}$ Radical-Initiated Reaction of a Series of Aromatic Hydrocarbons, Environ. Sci. Technol., 43(3), 683-689, doi:10.1021/es8019098, 2009.

Barkley, M. P., Palmer, P. I., Kuhn, U., Kesselmeier, J., Chance, K., Kurosu, T. P., Martin, R. V., Helmig, D., and Guenther, A.: Net ecosystem fluxes of isoprene over tropical South America inferred from Global Ozone Monitoring Experiment (GOME) observations of HCHO columns, J. Geophys. Res., 113, D20304, doi:10.1029/2008JD009863, 2008.

Bellouin, N., Boucher, O., Haywood, J., et al.: Improved representation of aerosols for HadGEM2, Meteorological Office Hadley Centre, Technical Note 73, Met Office, Exeter, UK, 2007.

Bond, T. C., Streets, D. G., Yarber, K. F., Nelson, S. M., Woo, J.H., and Klimont, Z.: A technology-based global inventory of black and organic carbon emissions from combustion, J. Geophys. Res., 109, D14203, doi:10.1029/2003JD003697, 2004.

Bouwman, A. F., Lee, D. S., Asman, W. A. H., Dentener, F. J., van der Hoek, K. W., and Olivier, J. G. J.: A global high-resolution emission inventory for ammonia, Global Biogeochem. Cy., 11, 561-578, 1997.

Bouwman, A. F., Boumans, L. J. M., and Batjes, N. H.: Estimation of global $\mathrm{NH}_{3}$ volatilization loss from synthetic fertilizers and animal manure applied to arable lands and grasslands, Global Biogeochem. Cy., 16(2), 1024, doi:10.1029/2000GB001389, 2002.

Butler, T. M., Taraborrelli, D., Brühl, C., Fischer, H., Harder, H., Martinez, M., Williams, J., Lawrence, M. G., and Lelieveld, J.: Improved simulation of isoprene oxidation chemistry with the ECHAM5/MESSy chemistry-climate model: lessons from the GABRIEL airborne field campaign, Atmos. Chem. Phys., 8, 4529-4546, 2008,

http://www.atmos-chem-phys.net/8/4529/2008/.

Cantrell, C. A., Davidson, J. A., McDaniel, A. H., Shetter, R. E., and Calvert, J. G.: Temperature-dependent formaldehyde cross sections in the near-ultraviolet spectral region, J. Phys. Chem, 94, 3902-3908, 1990.

Compernolle, S., Ceulemans, K., and Müller, J.-F.: Influence of non-ideality on condensation to aerosol, Atmos. Chem. Phys., 9, 1325-1337, 2009, http://www.atmos-chem-phys.net/9/1325/2009/.

Dentener, F., Kinne, S., Bond, T., Boucher, O., Cofala, J., Generoso, S., Ginoux, P., Gong, S., Hoelzemann, J. J., Ito, A., Marelli, L., Penner, J. E., Putaud, J.-P., Textor, C., Schulz, M., van der Werf, G. R., and Wilson, J.: Emissions of primary aerosol and precursor gases in the years 2000 and 1750 prescribed data-sets for
AeroCom, Atmos. Chem. Phys., 6, 4321-4344, 2006, http://www.atmos-chem-phys.net/6/4321/2006/.

De Smedt, I., Müller, J.-F., Stavrakou, T., van der A, R., Eskes, H., and Van Roozendael, M.: Twelve years of global observations of formaldehyde in the troposphere using GOME and SCIAMACHY sensors, Atmos. Chem. Phys., 8, 4947-4963, 2008, http://www.atmos-chem-phys.net/8/4947/2008/.

Feierabend, K. J., Zhu, L., Talukdar, R. K., and Burkholder, J. B. Rate Coefficients for the $\mathrm{OH}+\mathrm{HC}(\mathrm{O}) \mathrm{C}(\mathrm{O}) \mathrm{H}$ (Glyoxal) Reaction between 210 and 390 K, J. Phys. Chem. A, 112(1), 73-82, 2008.

Fu, T.-M., Jacob, D. J., Palmer, P. I., Chance, K., Wang, Y. X., Barletta, B., Blake, D. R., Stanton, J. C., and Pilling, M. J.: Space-based formaldehyde measurements as constraints on volatile organic compound emissions in east and south Asia and implications for ozone, J. Geophys. Res., 112, D06312, doi:10.1029/2006JD007853, 2007.

Fu, T.-M., Jacob, D. J., Wittrock, F., Burrows, J. P., Vrekoussis, M., and Henze, D. K.: Global budgets of atmospheric glyoxal and methylglyoxal, and implications for formation of secondary organic aerosols, J. Geophys. Res., 113, D15303, doi:10.1029/2007JD009505, 2008.

Giglio, L.: Characterization of the tropical diurnal fire cycle using VIRS and MODIS observations, Remote Sens. Environ., 108, 407-421, 2007.

Guenther, A., Hewitt, C. N., Erickson, D., Fall, R., Geron, C., Graedel, T., Harley, P., Klinger, L., Lerdau, M., McKay, W. A., Pierce, T., Scholes, B., Steinbrecher, R., Tallamraju, R., Taylor, J., and Zimmerman, P.: A global model of natural volatile organic compound emissions, J. Geophys. Res., 100, 8873-8892, 1995.

Henze, D. K., Seinfeld, J. H., and Shindell, D. T.: Inverse modeling and mapping US air quality influences of inorganic $\mathrm{PM}_{2.5}$ precursor emissions using the adjoint of GEOS-Chem, Atmos. Chem. Phys., 9, 5877-5903, 2009,

http://www.atmos-chem-phys.net/9/5877/2009/.

Ieda, T., Kitamori, Y., Mochida, M., Hirata, R., Hirano, T., Inukai, K., Fujinuma, Y., and Kawamura, K.: Diurnal variations and vertical gradients of biogenic volatile and semi-volatile organic compounds at the Tomakamai larch forest station in Japan, Tellus, 58B, 177-186, doi:10.1111/j.1600-0889.2006.0179.x, 2006.

Ip, H. S. S., Huang, X. H. H., and Yu, J. Z.: Effective Henry's law constants of glyoxal, glyoxylic acid, and glycolic acid, Geophys. Res. Lett., 36, L01802, doi:10.1029/2008GL036212, 2009.

Jacob, D. J., Field, B. D., Li, Q., Blake, D. R., de Gouw, J., Warneke, C., Hansel, A., Wisthaler, A., Singh, H. B., and Guenther, A.: Global budget of methanol: constraints from atmospheric observations, J. Geophys. Res., 110, D08303, doi:10.1029/2004JD005172, 2005.

Kopacz, M., Jacob, D. J., Henze, D. K., Heald, C. L., Streets, D. G., and Zhang, Q.: Comparison of adjoint and analytical Bayesian inversion methods for constraining Asian sources of carbon monoxide using satellite (MOPITT) measurements of CO columns, J. Geophys. Res., 114, D04305, doi:10.1029/2007JD009264, 2009.

Kroll, J., Ng, N. L., Murphy, S. M., Varutbangkul, V., Flagan, R. C., and Seinfeld, J. H.: Chamber studies of secondary organic aerosol growth by reactive uptake of simple carbonyl compounds, J. Geophys. Res., 110, D23207, doi:10.1029/2005JD006004, 2005. 
Lee, Y.-N., Zhou, X., and Hallock, K.: Atmospheric carbonyl compounds at a rural southeastern United States site, J. Geophys. Res., 100(D12), 25933-25944, 1995.

Lee, Y.-N., Zhou, X., Kleinman, L. I., et al.: Atmospheric chemistry and distribution of formaldehyde and several multioxygenated carbonyl compounds during the 1995 Nashville/Middle Tennessee Ozone Study, J. Geophys. Res., 103(D17), 2244922462, 1998.

Lelieveld, J., Butler, T. M., Crowley, J. N., Dillon, T. J., Fischer, H., Ganzeveld, L., Harder, H., Lawrence, M. G., Martinez, M., Taraborrelli, D., and Williams, J.: Atmospheric oxidation capacity sustained by a tropical forest, Nature, 452, 737-740, 2008.

Liggio, J., Li, S.-M., and McLaren, R.: Reactive uptake of glyoxal by particulate matter, J. Geophys. Res., 110(D10304), doi:10.1029/2004JD005113, 2005.

Martin, R. V., Jacob, D. J., Yantosca, R. M., Chin, M., and Ginoux, P.: Global and regional decreases in tropospheric oxidants from photochemical effects of aerosols, J. Geophys. Res., 108(D3), 4097, doi:10.1029/2002JD002622, 2003.

Matsunaga, S., Mochida, M., and Kawamura, K.: Variation on the atmospheric concentrations of biogenic carbonyl compounds and their removal processes in the northern forest at Moshiri, Hokkaido Island in Japan, J. Geophys. Res., 109, D04302, doi:10.1029/2003JD004100, 2004.

Metzger S., Dentener, F., Pandis, S., and Lelieveld, J.: Gas/aerosol partitioning, 1, A computationally efficient model, J. Geophys. Res., 107(D16), 4312, doi:10.1029/2001JD001102, 2002.

Middleton, P., Stockwell, P. W. R., and Carter, W. P.: Aggregation and analysis of volatile organic compound emissions for regional modeling, Atmos. Environ., 24A(5), 1107-1133, 1990.

Mircea, M., Facchini, M. C., Decesari, S., Cavalli, F., Emblico, L., Fuzzi, S., Vestin, A., Rissler, J., Swietlicki, E., Frank, G., Andreae, M. O., Maenhaut, W., Rudich, Y., and Artaxo, P.: Importance of the organic aerosol fraction for modeling aerosol hygroscopic growth and activation: a case study in the Amazon Basin, Atmos. Chem. Phys., 5, 3111-3126, 2005, http://www.atmos-chem-phys.net/5/3111/2005/.

Moortgat, G. K., Grossmann, D., Boddenberg, A., et al.: Hydrogen peroxide, organic peroxides and higher carbonyl compounds determined during BERLIOZ campaign, J. Atmos. Chem., 42, 443-463, 2002.

Munger, J., Jacob, D., Daube, B., Horowitz, L., Keene, W., and Heikes, B.: Formaldehyde, glyoxal, and methylglyoxal in air and cloudwater at a rural mountain site in central Virginia, J. Geophys. Res., 100(D5), 9325-9333, 1995.

Müller, J.-F. and Stavrakou, T.: Inversion of $\mathrm{CO}$ and $\mathrm{NO}_{\mathrm{x}}$ emissions using the adjoint of the IMAGES model, Atmos. Chem. Phys., 5, 1157-1186, 2005,

http://www.atmos-chem-phys.net/5/1157/2005/.

Müller, J.-F., Stavrakou, T., Wallens, S., De Smedt, I., Van Roozendael, M., Potosnak, M. J., Rinne, J., Munger, B., Goldstein, A., and Guenther, A. B.: Global isoprene emissions estimated using MEGAN, ECMWF analyses and a detailed canopy environment model, Atmos. Chem. Phys., 8, 1329-1341, 2008, http://www.atmos-chem-phys.net/8/1329/2008/.

Myriokefalitakis, S., Vrekoussis, M., Tsigaridis, K., Wittrock, F., Richter, A., Brühl, C., Volkamer, R., Burrows, J. P., and Kanakidou, M.: The influence of natural and anthropogenic secondary sources on the glyoxal global distribution, Atmos. Chem. Phys.,
8, 4965-4981, 2008,

http://www.atmos-chem-phys.net/8/4965/2008/.

Nenes, A., Pilinis, C., and Pandis, S. N.: Isorropia: A new thermodynamic model for multiphase multicomponent inorganic aerosols, Aquat. Geochem., 4, 123-152, 1998.

Nichitiu, F., Drummond, J. R., Zou, J., and Deschambault, R.: Solar particle events seen by the MOPITT instrument, J. of Atmos. Sol.-Terr. Phy., 66, 1797-1803, 2004.

Olivier, J .G. J., Berdowski, J. J. M., Peters, J. A. H. W., Bakker, J., Visschedijk, A. J. H., and Bloos, J.-P. J.: Applications of EDGAR, Including a description of EDGAR 3.0: reference database with trend data for 1970-1995, RIVM report no. 773301 001/ NOP report no. 410200 051, RIVM, Bilthoven, 2001.

Olivier, J. G. J.: Part III: Greenhouse gas emissions. 1. Shares and trends in greenhouse gas emissions; 2. Sources and methods: greenhouse gas emissions for 1990 and 1995 in " $\mathrm{CO}_{2}$ emissions from fuel combustion 1971-2000”, International Energy Agency, Paris, ISBN 92-64-09794-5, 1-31, 2002.

Olivier, J .G. J., Peters, J., Granier, C., Pétron, G., Müller, J.-F., and Wallens, S.: Present and future surface emissions of atmospheric compounds, POET Report 2, EU project EVK2-199900011, 2003

Olivier, J. G. J., Van Aardenne, J. A., Dentener, F., Ganzeveld, L., and Peters, J. A. H. W.: Recent trends in global greenhouse gas emissions: regional trends and spatial distribution of key sources, in: "Non- $\mathrm{CO}_{2}$ Greenhouse Gases (NCGG-4)", edited by: van Amstel, A., Millpress, Rotterdam, ISBN 905966043 9, 325 330, 2005.

Pang, Y., Thrpin, B. J., and Gundel, L. A.: On the importance of organic oxygen for understanding organic aerosol particles, Aerosol Sci. Tech., 40(2), 128-133, 2006.

Park, R. J., Jacob, D. J., Field, B. D., Yantosca, R. M., and Chin, M.: Natural and transboundary pollution influences on sulfate-nitrate-ammonium aerosols in the United States: Implications for policy, J. Geophys. Res., 109, D15204, doi:10.1029/2003JD004473, 2004.

Peeters, J., Nguyen, T. L., and Vereecken, L.: $\mathrm{HO}_{\mathrm{x}}$ radical regeneration in the oxidation of isoprene, Phys. Chem. Chem. Phys., 11, 5935-5939, doi:10.1039/b908511d, 2009.

Pham, M., Müller, J.-F., Brasseur, G. P., Granier, C., and Megie, G.: A three-dimensional study of the tropospheric sulfur cycle, J. Geophys. Res., 100(D12), 26061-26092, 1995.

Platt, U.: Differential Optical Absorption Spectroscopy (DOAS), in: Air Monitoring by Spectroscopic Techniques, edited by: Sigrist, M. W., John Wiley and Sons, Inc., New York, 1994.

Pöschl, U., von Kuhlmann, R., Poisson, N., and Crutzen, P. J.: Development and intercomparison of condensed isoprene oxidation mechanisms for global atmospheric modeling, J. Atmos. Chem., 37, 29-52, 2000.

Rissler, J., Vestin, A., Swietlicki, E., Fisch, G., Zhou, J., Artaxo, P., and Andreae, M. O.: Size distribution and hygroscopic properties of aerosol particles from dry-season biomass burning in Amazonia, Atmos. Chem. Phys., 6, 471-491, 2006, http://www.atmos-chem-phys.net/6/471/2006/.

Sander, S. P., Finlayson-Pitts, B. J., Friedl, R. R., Golden, D. M., Huie, R. E., Keller-Rudek, H., Kolb, C. E., Kurylo, M. J., Molina, M. J., Moortgat, G. K., Orkin, L. V., Ravishankara, A. R., and Wine, P. H.: Chemical Kinetics and Photochemical data for use 
in atmospheric studies, Evaluation number 15, NASA Panel for data evaluation, JPL Publication 06-2, Jet Propulsion Laboratory, Pasadena, 2006.

Saunders, S. M., Jenkin, M. E., Derwent, R. G., and Pilling, M. J.: Protocol for the development of the Master Chemical Mechanism, MCM v3 (Part A): tropospheric degradation of nonaromatic volatile organic compounds, Atmos. Chem. Phys., 3, 161-180, 2003, http://www.atmos-chem-phys.net/3/161/2003/.

Schultz, M. G., Backman, L., Balkanski, Y., et al.: REanalysis of the TROpospheric chemical composition over the past 40 years (RETRO): A long-term global modeling study of tropospheric chemistry, Jülich/Hamburg, Germany, 48/2007 report on Earth System Science of the Max Planck Institute for Meteorology, Hamburg, http://retro.enes.org, ISSN 1614-1199, 2007.

Spaulding, R. S., Schade, G. W., Goldstein, A. H., and Charles, M. J.: Characterization of secondary atmospheric photooxidation products: Evidence for biogenic and anthropogenic sources, J. Geophys. Res., 108(D8), 4247, doi:10.1029/2002JD002478, 2003.

Stavrakou, T., and Müller, J.-F.: Grid-based versus big region approach for inverting $\mathrm{CO}$ emissions using Measurement of Pollution in the Troposphere (MOPITT) data, J. Geophys. Res., 111, D15304, doi:10.1029/2005JD006896, 2006.

Stavrakou, T., Müller, J.-F., Boersma, K. F., De Smedt, I., and van der A, R. J.: Assessing the distribution and growth rates of $\mathrm{NO}_{\mathrm{x}}$ emission sources by inverting a 10-year record of $\mathrm{NO}_{2}$ satellite columns, Geophys. Res. Lett., 35, L10801, doi:10.1029/2008GL033521, 2008.

Stavrakou, T., Müller, J.-F., De Smedt, I., Van Roozendael, M., van der Werf, G. R., Giglio, L., and Guenther, A.: Evaluating the performance of pyrogenic and biogenic emission inventories against one decade of space-based formaldehyde columns, Atmos. Chem. Phys., 9, 1037-1060, 2009a,

http://www.atmos-chem-phys.net/9/1037/2009/.

Stavrakou, T., Müller, J.-F., De Smedt, I., Van Roozendael, M., van der Werf, G. R., Giglio, L., and Guenther, A.: Global emissions of non-methane hydrocarbons deduced from SCIAMACHY formaldehyde columns through 2003-2006, Atmos. Chem. Phys., 9, 3663-3679, 2009b, http://www.atmos-chem-phys.net/9/3663/2009/.

Tie, X., Brasseur, G., Emmons, L., Horowitz, L., and Kinnison, D.: Effects of aerosols on tropospheric oxidants: A global model study, J. Geophys. Res., 106, 2931-2964, 2001.

van der Werf, G. R., Randerson, J. T., Giglio, L., Collatz, G. J., Kasibhatla, P. S., and Arellano Jr., A. F.: Interannual variability in global biomass burning emissions from 1997 to 2004, Atmos. Chem. Phys., 6, 3423-3441, 2006,

http://www.atmos-chem-phys.net/6/3423/2006/.
Volkamer, R., Platt, U., and Wirtz, K.: Primary and Secondary Glyoxal Formation from Aromatics: Experimental Evidence for the Bicycloalkyl-Radical Pathway from Benzene, Toluene, and pXylene, J. Phys. Chem. A, 105, 7865-7874, 2001.

Volkamer, R., Spietz, P., Burrows, J. P., and Platt, U.: Highresolution absorption cross section of Glyoxal in the UV/vis and IR spectral ranges, J. Photoch. Photobio. A, 172, 35-46, doi:10.1016/j.jphotochem.2004.11.011, 2005a.

Volkamer, R., Barnes, I., Platt, U., Molina, L. T., and Molina, M. J.: Remote Sensing of Glyoxal by Differential Optical Absorption Spectroscopy (DOAS): Advancements in Simulation Chamber and Field Experiments, NATO Sciences Series, IV, Earth and Environmental Sciences, "Environmental Simulation Chambers: Application to Atmospheric Chemical Processes", edited by: Barnes, I. and Rudzinski, K. J., Kluwer Academic Publishers, Dordrecht, The Netherlands, ISBN: 1-4020-4231-0, Vol. 62, 2005b.

Volkamer, R., San Martini, F., Salcedo, D., Molina, L. T., Jimenez, J. L., and Molina, M. J.: A Missing Sink for Gas-Phase Glyoxal in Mexico City: Formation of Secondary Organic Aerosol, Geophys. Res. Lett., 34, L19807, doi:10.1029/2007GL030752, 2007.

Volkamer, R., Ziemann, P. J., and Molina, M. J.: Secondary Organic Aerosol Formation from Acetylene $\left(\mathrm{C}_{2} \mathrm{H}_{2}\right)$ : seed effect on SOA yields due to organic photochemistry in the aerosol aqueous phase, Atmos. Chem. Phys., 9, 1907-1928, 2009, http://www.atmos-chem-phys.net/9/1907/2009/.

Vrekoussis, M., Wittrock, F., Richter, A., and Burrows, J. P.: Temporal and spatial variability of glyoxal as observed from space, Atmos. Chem. Phys., 9, 4485-4504, 2009, http://www.atmos-chem-phys.net/9/4485/2009/.

Wang, J., Hoffmann, A. A., Park, R. J., Jacob, D. J., and Martin, S. T.: Global distribution of solid and aqueous sulfate aerosols: Effect of the hysteresis of particle phase transitions, J. Geophys. Res., 113, D11206, doi:10.1029/2007JD009367, 2008.

Wesely, M. L.: Parameterization of surface resistances to gaseous dry deposition in regional-scale numerical models, Atmos. Environ., 23, 1293-1304, 1989.

Wittrock, F., Richter, A., Oetjen, H., Burrows, J. P., Kanakidou, M., Myriokefalitakis, S., Volkamer, R., Beirle, S., Platt, U., and Wagner, T.: Simultaneous global observations of glyoxal and formaldehyde from space, Geophys. Res. Lett., 33, L16804, doi:10.1029/2006GL026310, 2006.

Xiao, Y., Jacob, D. J., and Turquety, S.: Atmospheric acetylene and its relationship with $\mathrm{CO}$ as an indicator of air mass age, J. Geophys. Res., 112, D12305, doi:10.1029/2006JD008268, 2007. 